\title{
Role of Reflexive Characteristics of Agents in the Level of Consistency of Goals in the Group
}

\author{
TURLAKOVA SVITLANA \\ Department of Financial and Economic Problems of Production Potential Employment \\ Institute of Industrial Economics of the National Academy of Sciences of Ukraine \\ 2, Marii Kapnist Str., Kyiv, 03057 \\ UKRAINE \\ VYSHNEVSKYI OLEKSANDR \\ Department of Regulatory Policy and Entrepreneurial Development \\ Institute of Industrial Economics of the National Academy of Sciences of Ukraine \\ 2, Marii Kapnist Str., Kyiv, 03057 \\ UKRAINE \\ LOHVINENKO BOHDAN \\ Post Graduate Department \\ Institute of Industrial Economics of the National Academy of Sciences of Ukraine \\ 2, Marii Kapnist Str., Kyiv, 03057 \\ UKRAINE \\ FOMICHENKO INNA \\ Department of Management \\ Donbass State Engineering Academy \\ 39, Mashinobudivnykiv blvd., Kramators `k, 84313 \\ UKRAINE
}

\begin{abstract}
The paper presented the test of the hypothesis about the importance of the role of reflexive characteristics in determining the level of consistency of the goals of agents in the group. Based on theoretical analysis, five main reflexive components of the decision-making process were established: awareness of agents regarding the area of decision; competence of agents; the authority (reputation) of the agent; propensity to imitate; intentional orientation of agents. The applied part of the study is based on a survey of 4 groups of agents. The results of the survey showed that the duration of the joint activities of the groups does not provide an increase in the quality of goal setting, the effectiveness of their implementation and the overall consistency of personal and group goals of agents. It was found that the reflexive components impact to achievement of personal goals. The higher the awareness of the goals of classmates and the competence of the agents, the higher the level of interest of each of the agents in the group for their own and group goals. As result there is the higher the probability of their achievement. Also a close relationship between the agents' reflexive characteristics and the level of consistency of goals in the group was established. Therefore, the hypothesis of essential role of reflexive characteristics in consistency of goals within a group of agents should be considered confirmed. In these conditions, for the agent, a winning strategy (from the standpoint of achieving personal goals) is the desire to coordinate their activities with the goals of the group and its individual members, as well as to participate in achieving the goals of other members of the group.
\end{abstract}

Key-Words: - reflexive approach, reflexive characteristics, agents, consistency, goal, group.

Received: November 11, 2019. Revised: April 25, 2020. Accepted: May 2, 2020. Published: May 12, 2020.

\section{Introduction}

The activity of any group of agents is determined by the its focus. The goal is commonly defined as the final result, towards which the action is directed to [1] or the conscious image of the anticipated result [2]. Although "to enhance performance organizations set individual and organizational goals" [3], however, aligning individual goals with a 
group's strategy is not an easy task [4], that remains unsolved.

In groups, the opinions of all the participants in the decision-making process are often diverse, which can lead to inefficiency in setting personal goals for group members, inconsistency of personal goals with group ones. This can cause ineffective functioning of the group as a whole. Most often it happens due to the fact that decision-making takes place in conditions of limited information exchange, when group members are poorly informed about the area of decision-making or, vice versa, are sufficiently informed, but pursue their own goals, which may contradict the general goals of the group [5-6].

Taking into consideration everything above mentioned, the essential condition for any group to function effectively is the consistency of agents' personal goals with the goals of the group as a whole. The decision coordination is customary determined as the procedure of achieving recognition of a certain (necessary and supposed) solution of a problem by a community or a group of people. The goal setting in a group is a decisionmaking process of choosing personal and group goals.

In October 2017, Richard Thaler received the Nobel Prize for his contribution to the study of behavioral economics. The work [7], which received the Nobel Prize, deals with the influence of economic agents' reflexive characteristics on the choice and, consequently, on the results of decision-making. Moreover, the author [7] proved that the agents' reflexive characteristics in the decision-making process predetermine in their behavior.

Indeed, the reflexive approach is the mainstream of modern economic science, which is necessary to use while studying the process of goal setting in groups of agents. Goal setting is a decision-making process, the result of which is the determination of the personal goals of the agents and the goals of the groups within which the agent operates. At the same time, it is important how much the agents' personal goals correspond to the general group goals.

Thus, the necessity to take into account the psychological characteristics of agents generating goals determines the relevance of using the reflective approach to assess the level of consistency of goals in groups of agents.

\section{Problem Formulation}

A study of the reflexive components of the goal setting processes and the coordination of personal and group goals of agents in groups reveal a deeper understanding of social relations. It affects the establishment of social relations that regulate the behavior of group' agents in order to optimize it later.

The relevance of using the reflexive approach in the processes of goal setting and coordination of personal and group goals of agents is due to the need to take into account the psychological characteristics of decision-makers.

The use of the reflexive approach for the study and formalization of economic interactions is due to the fact that today no economist who writes about group behavior can do without considering the psychological and mental characteristics of the decision-making process [8]. The subject of reflexive research is the methods of an objective description of systems along with their subjective knowledge of themselves and other systems [9].

The reflexive approach is based on the fact that decision-making by the agent is always based on information both of external origin (advertising, statistics, legislative acts, etc.) and internal (experience, intuition of decision makers).

In general, reflexion (from lat. reflexio - turning back, reflection) is a form of thinking, as well as the study of a cognitive act [10]. On the one hand "reflexion" is defined as "reflection, the study of a cognitive act" [11]. On the other hand, "reflexion" is "a form of cognition, a theoretical activity of a person aimed at comprehending his own actions and their foundations" or "awareness and study of the discrepancy between objective reality and its reflection in the human mind" [12].

Thus, reflexion is a process or mechanism due to which a person's ability to manage own state changes is realized through transmit specially prepared information to a partner or opponent. The study of reflexive mechanisms in the process of interactions of agents in groups allows to build a system of psychological characteristics of decisionmaking by subjects and to increase the consistency of personal and group goals in the process of goal setting in the group.

Indeed, the reflexive components of the decisionmaking process by economic entities mediate the choice of control agents for a particular decision (goal) and determine their behavior. In papers [1315], cognitive distortions in judgments were identified, which are manifested in the process of decision-making by agents to a group and are associated with their behavior. Among them, the following distortions can be distinguished:

- $\quad$ effect of general imitation, conformism the tendency to do (or believe) in things, because many other people do it (or believe in it). Refers to group thinking, herd behavior and mania; 
- the effect of acquaintance with an object is the tendency of people to express unreasonable sympathy for an object only because they are familiar with it or someone from a close circle or an authoritative person is familiar with it;

- $\quad$ preference for zero risk - the preference to reduce one small risk to zero instead of significantly reducing another, greater risk (for example, the risk of standing out from the general mass, the collective, etc. in deciding against the general opinion);

- $\quad$ submission to authority - the tendency of people to obey authority, ignoring their own judgments about the appropriateness of action.

Indeed, the above cognitive distortions reflect the essence of reflexive processes in decision-making by agents in groups and affect not only the decisionmaking process by agents, but also its result.

Recent studies [16-17] related to goal-setting in the context of reflexive management focused on issues of motivation and achieving goals. So the research A. Moore et al «highlighting the importance of matching one's personal goals to one's traits. Individuals who pursue more self concordant goals (e.g., when more extraverted individuals pursue communal goals or more conscientious individuals pursue agentic goals) tend to benefit motivationally in terms of feeling more autonomous, which is predictive of more successful goal pursuit" [16].

However, the problem of using the reflective approach to assess the level of consistency of goals in groups of agents remain unresolved. Therefore, the purpose of the article is to test the hypothesis about the essential role of reflexive characteristics in consistency of goals within a group of agents.

\section{Problem Solution}

\subsection{Theoretical background}

Among the main reflexive components of the decision-making process, which determine the irrationality and the presence of corresponding cognitive distortions in the decision-making process by agents in groups, and as a result, determining the degree of coordination of the goals of agents in groups, can be identified [18-20]:

- $\quad$ awareness of agents regarding the area of decision;

$\begin{array}{ll}- & \text { competence of agents; } \\ - & \text { the authority (reputation) of the agent; } \\ - & \text { propensity to imitate; } \\ - & \text { intentional orientation of agents. }\end{array}$

Let us consider in more detail the main reflexive components of the decision-making process by goal- setting agents that mediate the choice of specific goals in the group and determine their behavior.

The degree of awareness of the agent at some point in time is determined by the presence / absence of information from the agent about the subject area of goal-setting. Moreover, the lack of such information from the agent forces him to look for arguments for making the "right" decision and fill the gap in awareness at the expense of other agents. Thus, the lack of information from the agent about the subject area of decision-making on setting specific goals leads to imitation of other authoritative agents in the process of goal-setting. In this case, the lower the level of awareness of the agent about the subject of goal-setting, the greater the likelihood of imitation in the process of setting goals for other agents and, as a result, imitation of behavior in the process of achieving them.

The competence of the management agent is determined by the presence of knowledge and experience necessary for effective goal-setting in a given subject area. The knowledge and experience of agents' own activities allow them to make objective judgments and make the right decisions. The lower the agent's level of competence, the higher the likelihood that, in the process of goal setting, the agent will imitate other authoritative and more competent agents. Moreover, the manifestation of imitation is explained by the agent's attempts to fill the gaps in his own knowledge and lack of experience in the field of goal-setting. The use of such information about the area of decision-making will increase the consistency of goals in the group, because will provide a low percentage of accounting for his own goals [20].

The authority of an agent is determined by its influence, based on its position, status, possession of recognized authority or outstanding and recognized knowledge and experience. Reputable agents tend to make decisions on their own. Agents whose authority level is low in the field of decision-making are unsure in correctness of their decisions. Such agents tend to imitate those whose authority with them is not in doubt. In this case, the reflexive approach is manifested in the recognition by the agents of the authority of other agent leaders and/or the majority opinion in the group. As well as reflexivity consists in recognition of outstanding achievements, knowledge, skills, abilities of an authoritative agent. This determines his significance for group agents in the field of decision-making (goal-setting) and based on this voluntary submission (copying goals) [21]. 
The tendency to imitate agents, among other conditions listed above, is manifested when there is limited time for making a decision. When reducing the time for making a decision on setting goals, management agents are not able to fill the lack of awareness, increase their competence or authority in the field of the decision and, as a result, the agents become exposed to herd behavior and tend to obey the opinion / example of a leader and / or most agents. Thus, an effective reflexive control action for the characteristic in question in the process of agreeing goals in the group is to establish the timing of the decision. Moreover, the less time agents have for setting goals, the greater the likelihood of herd behavior.

The values of the estimates of intentions, which determine the value of a particular goal for a particular agent at some point in time, also determine the tendency of agents to imitate the opinion of most other agents and or the leader in the process of goal setting. With small values of their own intentions (in the absence of their own desires/intentions regarding the area of goal-setting), agents tend to obey the leader/majority of other agents due to their own inertia. The probability/ability to impose "necessary" goals in the process of coordinating decisions increases. In this case, an additional reflexive element in coordinating goals in a group can be additional informing agents about the importance and necessity of specific goals and about the benefits of the "right" directions of goal setting. At the same time, the orientation of such agents to leaders / most other agents can increase the value of the "necessary" goal for the agent and ensure the achievement of the necessary goal-setting result for "center". The high values of the estimates of the agents' own intentions relative to the goal-setting area indicate that the degree of value (significance) for the agent of a specific goal in the group is large. And he already has some definite opinion about the goals and the agent is ready to make a choice in favor of one or another alternative.

\subsection{Practical testing of hypothesis}

To test the hypothesis about the importance of the role of reflexive characteristics in determining the degree of coordination of the goals of agents in a group, a survey of 4 groups of students was conducted (Table 1). Two groups of the first year of study (groups "C" and "D") and two groups from among senior courses (groups "A" and "B"). The survey involved 12 women and 48 men. One respondent did not indicate his gender. A total of 61 people took part in the survey.

Table 1. General characteristics of respondent groups

\begin{tabular}{cccccc}
\hline Group & $\begin{array}{c}\text { Number of } \\
\text { students }\end{array}$ & $\begin{array}{c}\text { Average age, } \\
\text { years }\end{array}$ & Female & $\begin{array}{r}\text { Sex } \\
\text { Male }\end{array}$ & Not indicated \\
\hline A & 14 & 19,42 & 1 & 13 & \\
B & 12 & 20,25 & 4 & 8 & \\
C & 16 & 17.38 & 5 & 11 & 1 \\
D & 19 & 17.56 & 2 & 16 & \\
\hline
\end{tabular}

To assess the degree of awareness of respondents, the following questions were suggested: "Do you have clear goals that you plan to achieve before the end of this year (or for a specific date in the next 3 years)?"; "Did you have goals at the beginning of last year?"; "Did you manage to achieve your goals last year?"; "Do you know the goals of your classmates (at least some of them)?"; "Do you know the general goals of your group?"; "Do your personal goals and those of your group agree?"; "Do you contribute to the achievement of common goals for the group?"

To assess the degree of competence of the respondents, the following questions were suggested: "How much do your knowledge allow you to achieve your goals?"; "How much do your knowledge allow you to contribute to achieving the goals of your classmates?"; "How much do your knowledge allow you to contribute to achieving common goals for your group?"

To assess the degree of authority of the respondents, the following questions were suggested: "How much does your authority contribute to the achievement of your personal goals?"; "How much does your authority contribute to achieving the goals of your classmates?"; "How much does your personal authority contribute to the achievement of the group's common goals?"; "How much does the authority of your classmates contribute to the achievement of your personal group goals?"; "How much does the authority of your classmates contribute to the achievement of the group's common goals?" 
To assess the degree of use of imitation, the respondents asked the following questions: "How often do you take an example from classmates when choosing goals?"; "How often do your classmates take an example from you when choosing goals?"; "How often do you take an example from classmates when achieving goals?"; "How often do your classmates take an example from you in actions aimed at achieving goals?"

To assess the degree of intentionality, the respondents were asked the following questions:
"How much are you interested in achieving your own goals?"; "How much are you interested in achieving the goals of your classmates?"; "How much are you interested in achieving your group's common goals?"

Answers to questions from the first block (awareness) showed that in each of the groups of respondents a significant number of agents have clear goals (Table 2) and it varies greatly (for group "A" $-21 \%$, for group "D" $-63 \%$ ).

Table 2. Answers to the question "Do you have clear goals that you plan to achieve before the end of this year (or for a specific date in the next 3 years)?"

\begin{tabular}{cccccccc}
\hline Group & $\begin{array}{c}\text { Know exactly what } \\
\text { goals they plan to } \\
\text { achieve }\end{array}$ & Quntity & $\begin{array}{c}\text { They approximately know } \\
\text { what goals they plan to } \\
\text { achieve }\end{array}$ & Don't know \\
& quantity & \% & Quantity & \% \\
\hline A & 3 & 21 & 10 & 71 & 1 & 7 \\
B & 4 & 33 & 8 & 67 & 0 & 0 \\
C & 6 & 38 & 9 & 56 & 1 & 6 \\
D & 12 & 63 & 5 & 26 & 2 & 11 \\
All & 25 & 41 & 32 & 52 & 4 & 7 \\
\hline
\end{tabular}

However, the total number of those who know and approximately know their goals reaches $93 \%$. And more than $60 \%$ of respondents know the goals of their classmates.

In terms of achieving goals, the situation also looks very positive. $33 \%$ of respondents managed to

Table 3. Answers to the question "Did you manage to achieve the goals last year?"

\begin{tabular}{ccccccccc}
\hline \multirow{2}{*}{ Group } & \multicolumn{2}{c}{ Yes } & \multicolumn{2}{c}{ Partially } & \multicolumn{2}{c}{ No } & \multicolumn{2}{c}{ No goals } \\
& quantity & \% & quantity & \% & quantity & \% & quantity & $\%$ \\
\hline A & 2 & 14 & 10 & 71 & 1 & 7 & 1 & 7 \\
B & 4 & 33 & 6 & 50 & 2 & 17 & 0 & 0 \\
C & 7 & 44 & 9 & 56 & 0 & 0 & 0 & 0 \\
D & 7 & 37 & 8 & 42 & 3 & 16 & 1 & 5 \\
All & 20 & 33 & 33 & 54 & 6 & 10 & 2 & 3 \\
\hline
\end{tabular}

The existing level of knowledge (competence) allows to fully achieve their goals $20 \%$ of the total number of respondents (for group "A" - 29\%; for group "B" $-8 \%$; for group " $C$ " $-25 \%$; for group " $D$ $"-16 \%)$ and partially achieve the goal of another $67 \%$ (for group "A" $-57 \%$; for group "B" $-58 \%$; for group "C" $-69 \%$; for group " $D$ " $-79 \%$ ).

The "authority" characterization also has a significant impact on achieving goals. For $30 \%$ of respondents, their authority significantly contributes to achieving goals. Another $33 \%$ said that their authority "not significantly" contributes to the achievement of goals.
Imitation is not a key characteristic in setting goals. Only 1 respondent ( $2 \%$ of the total sample) answered that "always" take an example from classmates when choosing goals. 59\% answered "rarely" (for group "A" - 57\%; for group "B" $83 \%$; for group "C" $-56 \%$; for group " $D$ " $-47 \%$ ) and $34 \%$ "never" (for group "A" $-29 \%$; for group "B" $-17 \%$; for group "C" $-31 \%$; for group " $D$ " $53 \%)$.

When achieving goals, the characteristic of "imitation" also does not play an important role. Only 3\% of respondents always take an example from classmates when achieving goals. About half 
$(52 \%)$ do this rarely and a third (34\%) never.

The characteristic "intentionality" significantly affects the achievement of one's own goals. Absolute interest and readiness to make maximum efforts to achieve the goal was indicated by $28 \%$ of respondents (for group " $\mathrm{A}$ " $-21 \%$; for group " $\mathrm{B}$ " $17 \%$; for group "C" $-31 \%$; for group " $D$ " - $37 \%$ ). "Average degree of interest and willingness to act with a certain incentive" was noted by $41 \%$ of respondents (for group " $\mathrm{A}$ " - 50\%; for group "B" $33 \%$; for group "C" $-38 \%$; for group " $\mathrm{D}$ " $-42 \%$ ).

Comparison of answers by groups shows that there is no uniformity of results for groups close in age characteristics. There is also no connection between the quality of goal-setting and achievement of goals, depending on the age of the group. In some cases, most of the representatives of the first-year students have goals (group "D") and higher efficiency in their implementation (group " $C$ "), than older groups of students ("A" and "B"). Thus, the duration of the joint activity of collectives does not necessarily provide an improvement in the quality of setting goals and the effectiveness of their implementation. The next stage of the study is the analysis of the influence of intra-group communication on the achievement of personal goals in the context of the characteristics of reflecxive management. Therefore, its object is the respondents who were able to achieve their goals $(33 \%$ of the entire sample, or 20 respondents). The remaining $67 \%$ are hereinafter referred to as "other respondents".

Among those who managed to achieve goals last year, $80 \%$ know the goals of their classmates. Among the respondents who gave other answers (partially, no, did not set goals), only 51\% were aware of the goals of classmates. Also, "succeed in goals" students better know the common goals of their group than other respondents $(45 \%$ and $29 \%$, respectively). The degree of coordination of personal goals and group goals among such respondents is also higher $(40 \%$ and $27 \%$, respectively).

Students who achieve their goals more often than other respondents more often contribute to the achievement of common goals for the group (30\% and $7 \%$ respectively).

In $15 \%$ of cases, the knowledge of respondents who "succeed in goals" contributes to the achievement of the goals of classmates. Their authority contributes to the achievement of the goals of classmates in $25 \%$ of cases. For respondents who achieve the goal worse (or do not achieve them), this percentage is only $2 \%$ and $10 \%$ respectively.

Moreover, respondents who are "successful" in terms of achieving their goals take an example (imitate) when they are achieved (60\% versus $44 \%$ for other respondents). They coordinate their activities with generally accepted norms, and are more interested in achieving the goals of their classmates $(10 \%$ against $0 \%)$, and in achieving the common goals of their group (5\% against $2 \%$ ).

Thus, awareness, competence, authority, imitation and intentionality of agents correlate with the achievement of personal goals (Fig. 1).

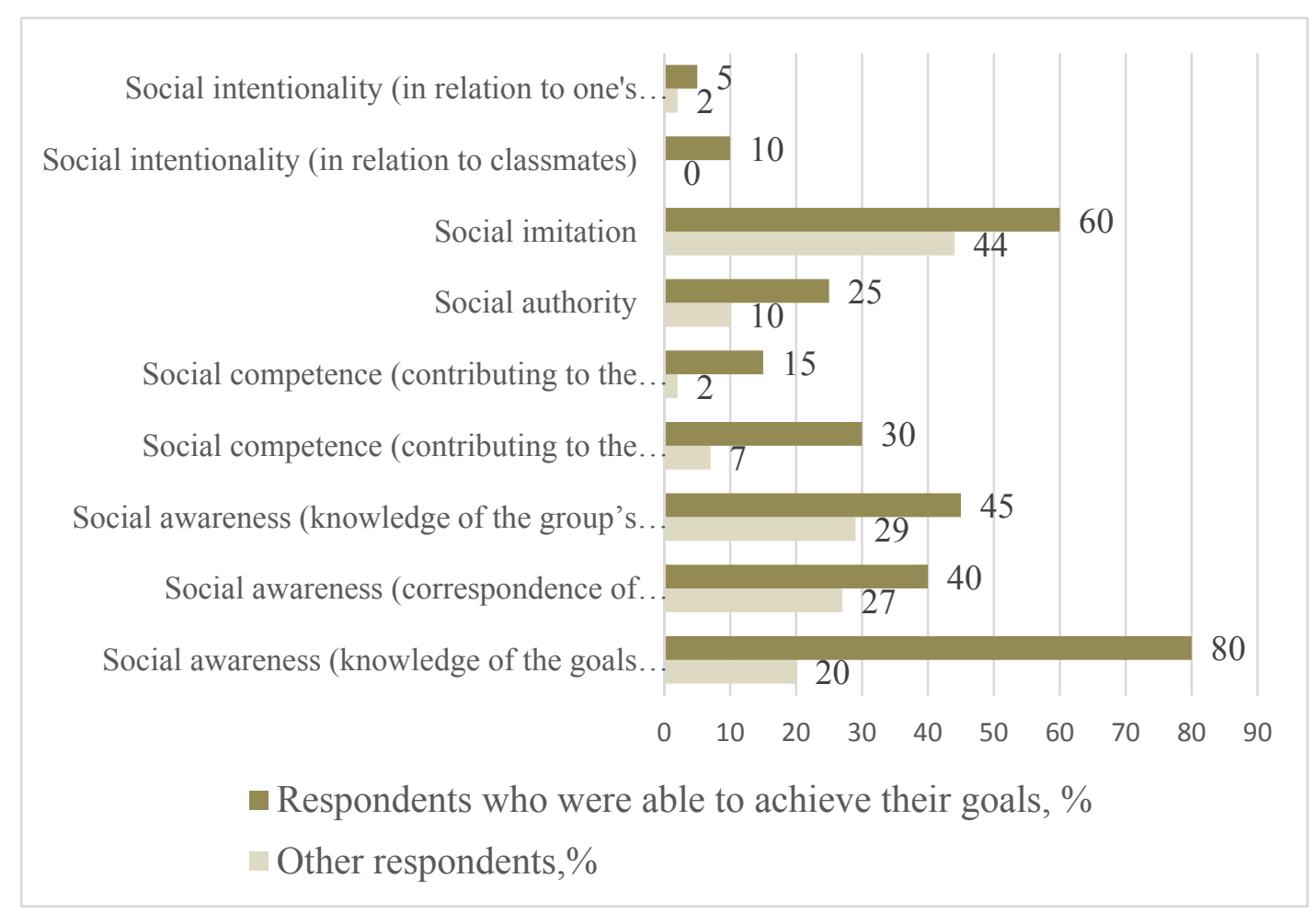


Fig.1. Reflexive characteristics in the context of agent-group communication

The relatively high level of awareness of the goals of classmates, the competence and authority of the agent, ensure the great interest of each of the agents in the group for their own and group goals. This leads to increasing likelihood of achieving the goals.

\section{Conclusion}

Thus, the article determines that the necessary condition for the effective functioning of any group is the consistency of the personal goals of the agents with common group goals. The relevance of applying the reflexive approach to assess the level of consistency of goals in groups of agents is substantiated by the need to take into account the psychological characteristics of subjects that develop goals.

Among the main reflexive components of the decision-making process: awareness, competence, authority of the agent, tendency of agents to imitate, intentional orientation. They mediate the agents' choice of a specific decision (goal) and their behavior in groups, as well as determine the degree of coordination of the goals of agents in groups.

To test the hypothesis about the importance of the role of reflexive characteristics in determining the degree of consistency of the goals of agents in the group, a survey of 4 groups of students was conducted using a specially designed questionnaire. The questions in the questionnaire were compiled in the selected areas for identifying the role of the reflexive characteristics of agents.

Comparison of answers in the context of groups age showed a lack of uniformity of results. There is no coherence between the quality of goal setting and their achievement for first-year students and older groups of students. The results of the survey showed that the duration of the joint activities of the groups does not provide an increase in the quality of goal setting, the effectiveness of their implementation and the overall consistency of personal and group goals of agents.

To analyze the impact of intra-group communication on achieving personal goals in the context of the characteristics of reflexive management, respondents who were able to achieve their goals (33\% of the entire sample) were considered. It was found that awareness, competence, authority, imitation and intentional orientation of agents correlate with the achievement of personal goals. The higher the awareness of the goals of classmates and the competence of the agent, the higher the level of interest of each of the agents in the group for their own and group goals. As result there is the higher the probability of their achievement.

Thus, as a result of the analysis of the survey results, a close relationship was established between the reflexive characteristics of group agents and the degree of consistency of goals in the group. It is determined that the level of awareness, competence, authority, imitation and intentional orientation of group agents determines the level of coordination of goals in the team. A higher level of awareness of agents, knowledge of the goals of other members of the group and the group as a whole, as well as involvement in their implementation provides a higher level of consistency of goals and a greater likelihood of achieving both individual and group goals.

Therefore, the hypothesis of the importance of the role of reflexive characteristics in determining the degree of consistency of the goals of agents in the group should be considered confirmed. In these conditions, for the individual, a winning strategy (from the standpoint of achieving personal goals) is the desire to coordinate their activities with the goals of the group and its individual members, as well as to participate in achieving the goals of other members of his group.

Thus, it can be assumed that an increase in the values of the reflexive characteristics of agents leads to an increase in the overall level of coordination of goals in the group and increases the number of agents that successfully achieve personal and group goals. Testing this hypothesis is a promising area for further research.

\section{References:}

[1] Locke E. A., Latham G. P., The development of goal setting theory: A half century retrospective, Motivation Science, Vol. 2, №5, 2019, pp. 93-105, doi:/10.1037/mot0000127.

[2] Greco L. M., Kraimer M. L., Goal-setting in the career management process: An identity theory perspective, Journal of Applied Psychology, Vol. 1, №105, 2020, pp. 4057, doi:10.1037/ap10000424

[3] Yurtkoru, E. S., T. Bozkurt, F. Bektas, M. J. Ahmed, V. Kola (2017). Application of goal setting theory. PressAcademia Procedia (PAP), V.3, p.796-801, http://doi.org/10.17261/ Pressacademia.2017.660

[4] Vishnevsky A.S., Obshchaya teoriya strategirovaniya: ot paradigmy $\mathrm{k}$ praktike 
ispolzovaniya. Kiev: NAS of Ukraine [General Strategic Theory: From Paradigm to Practical Use], Institute of Industrial Economics, 2018. [in Russian].

[5] Lohvinenko B.I., Rationale for the relevance of modeling reflexive management in the system of coordination of decisions at enterprises, Modern problems of social and economic systems modelling (MPSESM-X). Materials of $X$ International Scientific Practical Internet Conference, April 5-6 of 2018, 2018, pp. 196199.

[6] Vishnevsky A.S., The ideology of strategizing and technology of blockchain as tools for building the "kingdom of subjectness", Economic Herald of the Donbass, No.3 (53), 2018, pp. 31-35.

[7] Thaler R.H., Misbehaving: The Making of Behavioral Economics, New York: W.W. Norton J. (Eds.), 2015.

[8] Vishnevsky A.S., Strategic planning: introversion and extraversion of the strategist, Herald of Economic Science of Ukraine, Vol. 28, № 1, 2015, pp. 38-45 [in Russian].

[9] Lepa R.N., Refleksivnye processy v ekonomike: koncepcii, modeli, prikladnye aspekty, Doneck: APEKS, 2012 [in Russian].

[10] Lefevr V.A., Refleksiya, M: «Kogito-Centr», 2003 [in Russian].

[11] Philosophical Encyclopedic Dictionary, In Gubsky E.F., \&Korableva G.V, M.: Infra-M, 2003 [in Russian].

[12] Struk E.N., Refleksivnoe upravlenie kak instrument preodoleniya socialnyh predelov innovacionnogo razvitiya: socialno-filosofskij analiz, Teoriya i praktika obshestvennogo razvitiya, Vol. 4, 2011, pp. 17-19 [in Russian].

[13] Jones E.E., Harris V.A., The attribution of attitudes, Journal of Experimental Social Psychology, Vol. 3, 1967, pp. 1-24, doi:10.1016/0022-1031(67)90034-0.

[14] Jermias J., Cognitive dissonance and resistance to change: The influence of commitment confirmation and feedback on judgement usefulness of accounting systems, Accounting, Organizations and Society, Vol. 26, 2001, 141160, doi: 10.1016/S0361-3682(00)00008-8.

[15] Hilbert M., Toward a synthesis of cognitive biases: How noisy information processing can bias human decision making, Psychological Bulletin, Vol. 2, №138, 2012, pp/ 211-237, doi: $10.1037 / \mathrm{a} 0025940$.
[16] Moore A, Holding A, Verner Filion J, Harvey B, Koestner R. A longitudinal investigation of trait goal concordance on goal progress: The mediating role of autonomous goal motivation, Journal of Personality, 2019, pp. 1-14. https ://doi.org/10.1111/jopy. 12508

[17] Liang J., Augustine-Shaw D., Sottile J. An Exploration of New Superintendent Mentoring and Goal Setting, Journal of School Administration Research and Development, Vol. 5, No.1, 2019, pp. 6-17.

[18] Gontareva, I., Maryna, B., Babenko, V., Perevozova, I., Mokhnenko, A. (2019). Identification of efficiency factors for control over information and communication provision of sustainable development in higher education institutions. WSEAS Transactions on Environment and Development. Vol. 15, pp. 593-604.

[19] Turlakova S.S., Instrumenty refleksivnogo upravleniya stadnym povedeniem agentov na predpriyatiyah, Upravlinnya ekonomikoyu: teoriya ta praktika, 2017, pp. 133-149 [in Russian], uri: http://dspace.nbuv.gov.ua/handle/123456789/1 41376.

[20] Hrabovskyi, Y., Babenko, V., Al'boschiy, O., Gerasimenko, V. (2020). Development of a Technology for Automation of Work with Sources of Information on the Internet. WSEAS Transactions on Business and Economics, Vol. 17, Art. \#25, pp. 231-240. doi: $10.37394 / 23207.2020 .17 .25$

[21] Turlakova S.S., Syntez systemy refleksyvnoho upravlinnia stadnoiu povedinkoiu na pidpryiemstvakh, Modeliuvannia ta informatsijni systemy $v$ ekonomits, №97, 2019, pp. 219-229, doi: 10.33111/mise.97.21.

[22] Turlakova S.S., Refleksivnoe upravlenie stadnym povedeniem na predprijatijah: koncepcija, modeli $i$ metody, Kiev:NAN Ukrainy, In-t jekonomiki prom-sti, 2020.

\section{ACKNOWLEDGEMENT}

We would like to thank all the reviewers for their thoughtful comments and efforts towards improving our manuscript. We revised the manuscript with special attention to the comments that we received from 3 reviewers that they were experts, specialist in the area of our paper. 